\title{
Flame-Made $\mathrm{La}_{2} \mathrm{O}_{3}$-Based Nanocomposite $\mathrm{CO}_{2}$ Sensors as Perspective Part of GHG Monitoring System
}

\author{
Matvey Andreev ${ }^{1}$, Vadim Platonov ${ }^{1}$, Darya Filatova ${ }^{1}$, Elena Galitskaya ${ }^{2}$, Sergey Polomoshnov ${ }^{3} \oplus$, \\ Sergey Generalov ${ }^{3}$, Anastasiya Nikolaeva ${ }^{3}$, Vladimir Amelichev ${ }^{3}$, Oleg Zhdaneev ${ }^{2,4} \mathbb{C}^{(}$, Valeriy Krivetskiy ${ }^{1}(\mathbb{C})$ \\ and Marina Rumyantseva ${ }^{1, *(1)}$
}

1 Department of Chemistry, Lomonosov Moscow State University, 119991 Moscow, Russia; andreev@inorg.chem.msu.ru (M.A.); agnes1992@yandex.ru (V.P.); gak1.analyt@gmail.com (D.F.); vkrivetsky@inorg.chem.msu.ru (V.K.)

2 Russian Energy Agency, Ministry of Energy of the Russian Federation, 129085 Moscow, Russia; Galitskaya@rosenergo.gov.ru (E.G.); Zhdaneev@rosenergo.gov.ru (O.Z.)

3 Scientific-Manufacturing Complex Technological Centre, 124498 Moscow, Russia; S.Polomoshnov@tcen.ru (S.P.); s.generalov@tcen.ru (S.G.); A.Nikolaeva@tcen.ru (A.N.);

V.Amelichev@tcen.ru (V.A.)

4 A.V. Topchiev Institute of Petrochemical Synthesis, Russian Academy of Sciences, 119991 Moscow, Russia

* Correspondence: roum@inorg.chem.msu.ru

\section{check for} updates

Citation: Andreev, M.; Platonov, V.; Filatova, D.; Galitskaya, E.;

Polomoshnov, S.; Generalov, S.;

Nikolaeva, A.; Amelichev, V.;

Zhdaneev, O.; Krivetskiy, V.; et al.

Flame-Made $\mathrm{La}_{2} \mathrm{O}_{3}$-Based

Nanocomposite $\mathrm{CO}_{2}$ Sensors as

Perspective Part of GHG Monitoring

System. Sensors 2021, 21, 7297.

https://doi.org/10.3390/s21217297

Academic Editor: Antonios Kelarakis

Received: 2 October 2021

Accepted: 30 October 2021

Published: 2 November 2021

Publisher's Note: MDPI stays neutral with regard to jurisdictional claims in published maps and institutional affiliations.

Copyright: (c) 2021 by the authors. Licensee MDPI, Basel, Switzerland. This article is an open access article distributed under the terms and conditions of the Creative Commons Attribution (CC BY) license (https:// creativecommons.org/licenses/by/ $4.0 /)$.

\begin{abstract}
Continuous monitoring of greenhouse gases with high spatio-temporal resolution has lately become an urgent task because of tightening environmental restrictions. It may be addressed with an economically efficient solution, based on semiconductor metal oxide gas sensors. In the present work, $\mathrm{CO}_{2}$ detection in the relevant concentration range and ambient conditions was successfully effectuated by fine-particulate $\mathrm{La}_{2} \mathrm{O}_{3}$-based materials. Flame spray pyrolysis technique was used for the synthesis of sensitive materials, which were studied with X-ray diffraction (XRD), Fouriertransform infrared spectroscopy (FTIR), diffuse reflectance infrared Fourier transform spectroscopy (DRIFTs) and low temperature nitrogen adsorption coupled with Brunauer-Emmett-Teller (BET) effective surface area calculation methodology. The obtained materials represent a composite of lanthanum oxide, hydroxide and carbonate phases. The positive correlation has been established between the carbonate content in the as prepared materials and their sensor response towards $\mathrm{CO}_{2}$. Small dimensional planar MEMS micro-hotplates with low energy consumption were used for gas sensor fabrication through inkjet printing. The sensors showed highly selective $\mathrm{CO}_{2}$ detection in the range of 200-6667 ppm in humid air compared with pollutant gases $\left(\mathrm{H}_{2} 50 \mathrm{ppm}, \mathrm{CH}_{4} 100 \mathrm{ppm}\right.$, $\mathrm{NO}_{2} 1 \mathrm{ppm}$, NO 1 ppm, $\mathrm{NH}_{3} 20$ ppm, $\mathrm{H}_{2} \mathrm{~S} 1$ ppm, $\mathrm{SO}_{2} 1 \mathrm{ppm}$ ), typical for the atmospheric air of urbanized and industrial area.
\end{abstract}

Keywords: greenhouse gases; $\mathrm{CO}_{2}$; gas sensor; semiconductor; lanthanum oxide; nanocomposite

\section{Introduction}

Global climate change is directly correlated with anthropogenic greenhouse gas (GHG) emissions. For hundreds of years, the concentration of $\mathrm{CO}_{2}$ in the Earth's atmosphere did not exceed $300 \mathrm{ppm}$, but an increase in concentration began to be observed with the beginning of industrialization [1,2]. Today, the $\mathrm{CO}_{2}$ concentration is a record $417 \mathrm{ppm}$, having increased by three ppm in the last year alone. The energy sector contributes the most to climate change and is the source of about $50-60 \%$ of anthropogenic GHG emissions [3]. A change in temperature leads to disastrous consequences. Since the 1900s, the average temperature of the Earth's surface has increased by $\sim 1.07^{\circ} \mathrm{C}$, and the global sea level has risen by $\sim 0.2 \mathrm{~m}$. Anthropogenic $\mathrm{CO}_{2}$ emissions are the main reason for the decrease in the ice cover area and ocean acidification. The ocean acidity will reach $\mathrm{pH} \sim 7.7$ by the end of the century [4-6]. To keep the ambient temperature rise within $1.5^{\circ} \mathrm{C}$, according to the Paris 
Climate Agreement, global anthropogenic $\mathrm{CO}_{2}$ emissions should be reduced by about $45 \%$ by 2030 compared to the level of 2010 [7-11]. To limit global climate change and mitigate its consequences, it is necessary to achieve net-zero carbon dioxide emissions by 2050 . The path to net-zero GHG emissions requires all States to significantly strengthen their energy and climate policies. Thus, for the first time in the world, the EU has legislated a plan to achieve climate neutrality by 2050 with an interim goal of reducing GHG emissions by at least $55 \%$ by 2030 [12-16].

Achieving carbon neutrality is impossible without a clear accounting and control of emissions of carbon dioxide $\left(\mathrm{CO}_{2}\right)$, methane $\left(\mathrm{CH}_{4}\right)$ and nitrogen oxides $\left(\mathrm{NO}_{\mathrm{x}}\right)$ since the emissions of these gases are closely related to the human activity [17-19]. Today, the estimation of GHG emissions is mainly carried out by calculation methods with a high degree of uncertainty. The error in accounting for emissions of the main anthropogenic greenhouse gases $\left(\mathrm{CO}_{2}, \mathrm{CH}_{4}, \mathrm{NO}_{\mathrm{x}}\right)$ is $10-30 \%$, and at the country level can exceed $100 \%$. For the state accounting of GHG emissions, an important task is to create a unified system for monitoring the carbon balance, including accurate determination of emissions from the main GHG emitters, such as industry, housing, transport, agriculture, burning of fossil fuels and waste, etc., and a qualitative assessment of the sequestration potential of ecosystems. The architecture of the global carbon balance monitoring system is shown in Figure 1.

An integrated approach should provide a monitoring system at the global and local levels. On the one hand, remote monitoring of large areas is needed using unmanned aerial vehicles, high-orbit and low-orbit spacecraft equipped with instruments with high spatial and temporal resolutions. On the other hand, precise local control is needed using groundbased detection systems, including stationary gas analysis installations, mobile laboratories and wireless sensor networks. This approach includes measurements at different scales: a country level, a specific region or city, a single enterprise or plant, etc.

Reliable monitoring of the carbon balance of GHG emitters, such as fuel and energy companies, waste incineration plants, metallurgical plants, fertilizer production, etc., should be provided by remote sensing, unmanned aerial vehicles (UAVs) with appropriate equipment, and local ground-based monitoring systems. Ground-based sensors are also used to verify data from remote sensing. The local ground-based monitoring system must be applied to plants and enterprises whose activities are accompanied by GHG emissions, the mass of which is equivalent to 50,000 tons of $\mathrm{CO}_{2}$ per year. For monitoring GHG in hard-to-reach areas of the country (permafrost zones, bogs, taiga, etc.) or agricultural sectors, as well as for assessing the sequestration potential of soils and forests, a combination of wireless ground systems and mobile laboratories can be a relevant method. Unmanned aerial vehicles can supplement GHG observations by providing high-resolution vertical profiling, horizontal flow mapping and 3D measurements near the ground. For the global monitoring of GHG balance, remote sensing can be a powerful tool. With remote sensing, it is possible to measure GHG in places where ground-based monitoring is impossible or impracticable. The necessity of using measuring equipment at different heights is explained by the importance of solving the inverse problem; that is, studying the ecosystem sequestration potential. Also, an important task is to link instrumental measurements with a complex atmospheric model for predictive calculations of the plumes movement. The comprehensive methodology should include a strong verification component that collects independent data from different sources. Verification activities can be carried out on multiple spatial and temporal scales and include data from standard computational inventory methods, instrumental methods, remote sensing and modeling. All information must be processed by a hybrid data center system [20-28].

Currently, non-dispersive IR spectroscopy $\left(\mathrm{CO}_{2}\right)$, near-IR laser absorption spectroscopy $\left(\mathrm{CH}_{4}\right)$, portable laser analyzers based on CRDS (Cavity ring-down spectroscopy) and ICOS (Integrated cavity-output spectroscopy) $\left(\mathrm{N}_{2} \mathrm{O}\right)$ technologies are used to analyze concentrations and fluxes of greenhouse gases (including at meteorological stations and carbon landfills) [29-31]. The high cost of optical gas analyzers makes it impossible to deploy widespread networks for monitoring greenhouse emissions and air pollution in real time 
with high spatial resolution necessary to detect sources of emissions, assess their scale and promptly eliminate them. For this reason, research groups around the world are developing various sensor technologies for monitoring greenhouse gases [28,31,32]. A promising approach is the creation of widespread networks of miniature semiconductor gas sensors. The advantages of such sensors include low cost, high sensitivity, low gas detection limit, a wide range of detectable components, miniature size and low power consumption. Static networks of gas sensors can create a spatially resolved picture of pollution changes in cities, in various landscape systems, territories of industrial enterprises, zones of extraction, processing and transport of fossil fuels. Works are underway to improve the reliability of detection, including through data processing methods [33-41].

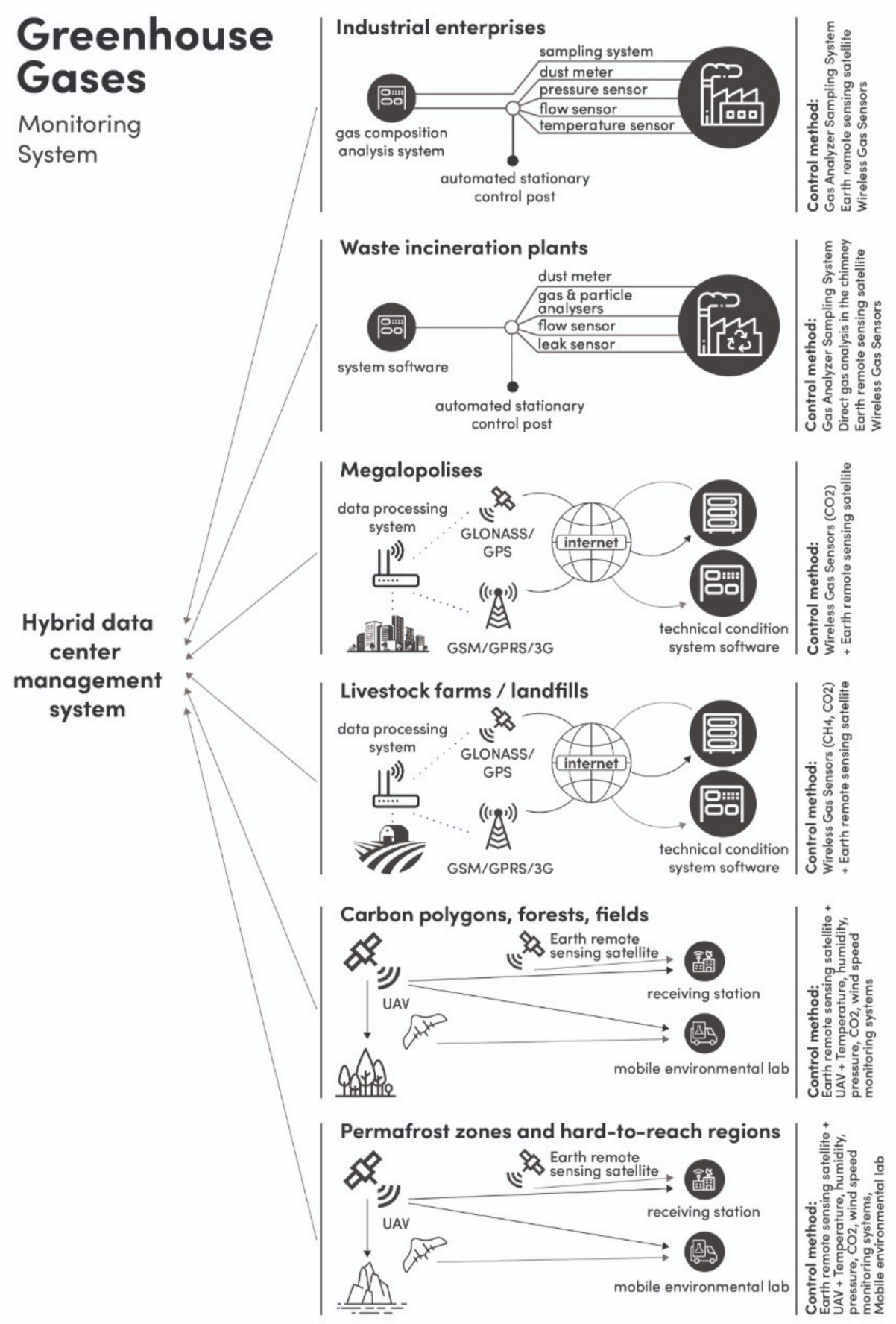

Figure 1. Architecture of the global carbon balance monitoring system. 
Carbon dioxide $\mathrm{CO}_{2}$ is the most common greenhouse gas of anthropogenic origin. Carbon dioxide is a rather inert substance, and its chemical contact with the semiconductor sensitive material has a weakly expressed chemisorption character. In the last decade, the sensitivity, selectivity, detection limit and response/recovery time of the semiconductor sensors in $\mathrm{CO}_{2}$ detection have been significantly improved due to the study of a wide range of materials and the development of new synthesis methods [28,32,38]. Some characteristics of metal oxide semiconductor (MOS) gas sensors are summarized in Table 1 [42-69]. The highest sensor response is demonstrated by materials based on lanthanum oxide [69]. However, for the widespread use of semiconductor sensors for continuous long-term monitoring of GHG in atmospheric air, it is still necessary: (i) to develop new materials with high selective sensitivity to target gases; (ii) to develop scalable technologies for the synthesis of materials and the formation of a sensitive layer that allows production of a large number of sensor elements with identical characteristics. For these reasons, in this article, sensitive materials based on lanthanum oxide were obtained by flame spray pyrolysis (FSP). The FSP method makes it possible to obtain both ultrafine powders of metal oxides for the subsequent formation of thick-film gas-sensitive elements, as well as directly form highly porous thick films of sensitive materials on the surface of MEMS-microheaters provided with electrode system for electrical measurements.

Table 1. Summary of literature data on sensor response $S=100 \% \times\left|R_{\mathrm{CO} 2}-R_{\text {air }}\right| / R_{\text {air }}$ of MOS gas sensors in $\mathrm{CO}_{2}$ detection.

\begin{tabular}{|c|c|c|c|c|c|}
\hline Material & Synthesis Method & $\mathrm{C}\left(\mathrm{CO}_{2}\right), \mathrm{ppm}$ & $\begin{array}{c}\text { Operating } \\
\text { Temperature, }{ }^{\circ} \mathrm{C}\end{array}$ & Response $^{1}$ & Ref. \\
\hline $\mathrm{BiOCl}-\mathrm{Au}$ & Surfactant assisted & 400 & 300 & 63 & [42] \\
\hline $\mathrm{ZnO}-\mathrm{SnO}_{2}$ & Spray pyrolysis & 500 & 300 & 90 & [43] \\
\hline $\mathrm{LaOCl}-\mathrm{SnO}_{2}$ & Electrospinning & 1000 & 300 & 270 & [44] \\
\hline $\mathrm{La}_{2} \mathrm{O}_{3}-\mathrm{ZnO}$ & Hydrothermal & 5000 & 400 & 65 & [45] \\
\hline $\mathrm{ZnO}$ & Spray pyrolysis & 400 & 350 & 64 & [46] \\
\hline $\mathrm{CdO}-\mathrm{CeO}_{2}$ & Co-precipitation & 800 & 250 & 45 & [47] \\
\hline $\mathrm{WO}_{3}-\mathrm{ZnO}$ & Mechanochemical & 1000 & 450 & 65 & [48] \\
\hline $\mathrm{La}_{2} \mathrm{O}_{2} \mathrm{CO}_{3}$ & Hydrothermal & 5000 & 300 & 62 & [49] \\
\hline $\mathrm{ZnO}-\mathrm{SnO}_{2}$ & Hydrothermal & 1000 & 150 & 350 & [50] \\
\hline $\mathrm{La}_{2} \mathrm{O}_{3}-\mathrm{SnO}_{2}-\mathrm{Au}$ & Electrospinning & 100 & 300 & 10 & [51] \\
\hline $\mathrm{SnO}_{2}$ & Co-precipitation & 2000 & 240 & 30 & [52] \\
\hline $\mathrm{SnO}_{2}$ & Mechanochemical & 1000 & 400 & 10 & [53] \\
\hline $\mathrm{La}_{2} \mathrm{O}_{3}$ & Chemical bath & 350 & 250 & 55 & [54] \\
\hline $\mathrm{LaOCl}$ & Sol-gel & 2000 & 260 & 240 & [55] \\
\hline $\mathrm{NdO}_{2} \mathrm{CO}_{3}$ & Sol-gel & 1000 & 350 & 300 & [56] \\
\hline $\mathrm{La}_{2} \mathrm{O}_{3} \mathrm{CO}_{3}$ & Co-precipitation & 3000 & 325 & 600 & [57] \\
\hline $\mathrm{LaFeO}_{3}$ & Sol-gel & 2000 & 300 & 120 & [58] \\
\hline $\mathrm{LaCaFeO}_{3}$ & Sol-gel & 1000 & 320 & 70 & [59] \\
\hline $\mathrm{LaOCl}-\mathrm{SnO}_{2}$ & Electrostatic spray pyrolysis & 2000 & 425 & 40 & [60] \\
\hline $\mathrm{CuO}-\mathrm{BaTiO}_{3}$ & Magnetron sputtering & 1000 & 250 & 80 & [61] \\
\hline $\mathrm{LaFeO}_{3}-\mathrm{SnO}_{2}$ & Mixing & 4000 & 250 & 170 & [62] \\
\hline $\mathrm{ZnO}-\mathrm{CuO}$ & Mixing & 4000 & 300 & 30 & [63] \\
\hline $\mathrm{SnO}_{2}-\mathrm{LaOCl}$ & Impregnation & 2000 & 350 & 150 & [64] \\
\hline $\mathrm{SnO}_{2}-\mathrm{LaOCl}$ & Drop-coating & 4000 & 400 & 580 & [65] \\
\hline $\mathrm{ZnO}-\mathrm{LaOCl}$ & Drop-coating & 2000 & 400 & 250 & [66] \\
\hline $\mathrm{SnO}_{2}-\mathrm{La}_{2} \mathrm{O}_{3}$ & Impregnation & 500 & 250 & 30 & [67] \\
\hline $\mathrm{La}_{2} \mathrm{O}_{3}-\mathrm{Pd}$ & Dipping & 500 & 250 & 40 & [68] \\
\hline $\mathrm{La}_{2} \mathrm{O}_{2} \mathrm{CO}_{3}$ & Thermal decomposition & 500 & 300 & 700 & [69] \\
\hline
\end{tabular}

${ }^{1}$ For correct comparison all the data were recalculated as $S=100 \% \times\left|R_{\mathrm{CO} 2}-R_{\text {air }}\right| / R_{\text {air }}$.

\section{Materials and Methods}

Gas sensitive materials were synthesized by the flame-spray pyrolysis (FSP) technique with the use of the setup, described previously [70]. La(III) -2-ethylhexanoate (LEH) has been used as precursor. LEH has been synthesized according to the following technique: first $\mathrm{La}(\mathrm{OH})_{3}$ was deposited from the $\mathrm{La}\left(\mathrm{NO}_{3}\right)_{3}$ aqueous solution by addition of excessive 
amounts of $\mathrm{NH}_{3} \cdot \mathrm{aq}$ ( $25 \%$ mass). The deposit was centrifugated and washed with distilled water 5 times. The obtained deposit was put into a flask with a Dean-Stark trap with reflux condenser and thermometer. The deposit was added with 10-fold excess of 2-ethylhexanoic acid and heated up to $175^{\circ} \mathrm{C}$ under continuous stirring until the end of water accumulation in the trap. The obtained yellowish viscous matter was separated in the separation funnel and studied in order to establish exact La content. The sample was taken in $100 \mu \mathrm{L}$ volume and treated with $500 \mu \mathrm{L}$ of concentrated nitric acid. After the sample decomposition, it was diluted by distilled water up to $10 \mathrm{~mL}$ of total volume. This solution was further diluted by distilled water 100 times prior to the analysis. La content was determined by total reflection X-ray fluorescence with the S2 PICOFOX instrument (Bruker Nano GmbH, Berlin, Germany). The diluted sample $(5 \mu \mathrm{L})$ was deposited on the quartz substrate, dried and analyzed. Mo $\mathrm{K}_{\alpha}$ radiation was used for X-ray fluorescence ignition. The spectra were collected for $250 \mathrm{~s}$. Internal La standard was used for calculations. The La content in the obtained LEH solution was $50 \mathrm{mg} / \mathrm{mL}$.

The LEH solution was diluted to $0.2 \mathrm{M}$ with toluene before FSP process. This mixture was supplied to the nozzle with $3 \mathrm{~mL} / \mathrm{min}$ rate and atomized with the oxygen flow at 3 bar pressure drop. Two different oxygen flow rates were used during synthesis, 2 and $1.5 \mathrm{~L} / \mathrm{min}$. The powder materials were collected on the glass fiber filters (Whatman GF/A), placed $90 \mathrm{~cm}$ above the nozzle with the aid of vacuum pump. The obtained powders were divided in two parts, one of which for each obtained material was annealed at $500{ }^{\circ} \mathrm{C}$ in the flow of dry clean air (dry clean air generator GChV 2.0, Himelektronika, Moscow, Russia) for $24 \mathrm{~h}$.

The as prepared materials were studied by X-ray diffraction (XRD) using a DRON-4M diffractometer $(\mathrm{Cu} \mathrm{K} \alpha, \lambda=1.5406)$. The crystallite size ( $\mathrm{dXRD})$ of phases in obtained materials was estimated using the Scherrer formula. The specific surface area was measured by low temperature nitrogen adsorption technique with the use of ChemiSorb 2750 apparatus (Micromeritics, Norcross, GA, USA) and further calculation according to BET model. The morphology of the powders was studied by scanning electron microscopy (SEM) using a Carl Zeiss SUPRA 40 FE-SEM instrument with Inlens SE detector (accelerating voltage $5 \mathrm{kV}$, aperture $30 \mu \mathrm{m}$ ). The Fourier-transform infrared (FTIR) spectra of samples in the transmittance mode were taken with a Frontier (Perkin Elmer, Walham, MA, USA) spectrometer in transmission mode within the range $400-4000 \mathrm{~cm}^{-1}$ with $1 \mathrm{~cm}^{-1}$ steps. The $7 \mathrm{~mm}$ diameter pellets of the samples were pressed from the $0.5 \mathrm{mg}$ of studied material finely grinded with $50 \mathrm{mg}$ of $\mathrm{KBr}$. In situ diffuse reflectance infrared Fourier transform (DRIFT) spectroscopy was used to investigate the solid-gas interactions. The spectra were registered by a Frontier (Perkin Elmer) spectrometer with the DiffusIR annex and flow chamber HC900 (Pike Technologies, Madison, WI, USA) sealed by a ZnSe window. The DRIFT spectra were registered in the wavenumber range of $800-4000 \mathrm{~cm}^{-1}$ with a resolution of $4 \mathrm{~cm}^{-1}$ and averaging 30 scans. The powders $(30 \mathrm{mg})$ were placed in alumina crucibles (5 mm diameter). The DRIFT spectra were registered at $410{ }^{\circ} \mathrm{C}$ under an exposure to humidified air flow $\left(100 \mathrm{~mL} / \mathrm{min}\right.$ ) containing $400 \mathrm{ppm} \mathrm{CO}_{2}$.

Sensors were fabricated with the use of micro-hotplates square, $2 \times 2 \mathrm{~mm}$ MEMS crystals, which were fabricated at the facility of Scientific-Manufacturing Complex "Technological centre" (Zelenograd, Russia). MEMS crystals have thin $(\sim 1.5 \mu \mathrm{m})$ dielectric membrane $\left(\mathrm{Si}_{3} \mathrm{~N}_{4}\right.$ on top of $\left.\mathrm{SiO}_{2}\right)$, which bears thin film Pt micro-heating element and $\mathrm{Pt}$ electrodes electrically insulated from each other by additional $\mathrm{SiO}_{2}$ layer (Figure $2 \mathrm{a}-\mathrm{c}$ ). The diameter of heated area is $300 \mu \mathrm{m}$, which results in $70 \mathrm{~mW}$ power consumption at $400{ }^{\circ} \mathrm{C}$. This, along with planar construction, makes this platform perspective from the view of scalability of sensor manufacturing. The crystals were fixed in TO-5 cases (Mars, Torzhok, Russia) using ultrasonic welding (Figure 2a). The obtained materials were deposited on the micro-hotplates in a form of suspensions by inkjet micro-printing technique. The suspension for printing of gas sensitive layers was prepared by ultrasonic treatment in an Elmasonic s15h bath (Elma, Singen, Germany) for $1 \mathrm{~h}$ at room temperature. To prepare the suspension, $10 \mathrm{mg}$ of powder were suspended in $1 \mathrm{~mL}$ of tetraethylene glycol 
dimethyl ether. The sensitive layer was deposited using a piezoelectric micro-dispenser NanoTip-HV (Gesim, Radeberg, Germany), which was coupled with lab-made positioning stage, featuring Nippon Bearing (Niigata, Japan) linear actuators and lab made optical microscope system with components, supplied by Altami (St. Petersburg, Russia). The frequency, duration and amplitude of the pulses are $100 \mathrm{~Hz}, 100 \mu \mathrm{s}$ and $120 \mathrm{~V}$, respectively. The calculated mass of the applied dry matter was $230 \mathrm{ng}$ (Figure 2d). After deposition, the binder was removed by ramp-heating of the micro-heater in air up to $500{ }^{\circ} \mathrm{C}$. The sensing element was kept at this temperature for $10 \mathrm{~h}$ to form a stable thick $(2-5 \mu \mathrm{m})$ porous film. The morphology of the deposited sensitive layer was investigated by scanning electron microscopy (SEM) with the use of JEOL JSM-6390 LA microscope (JEOL Ltd., Tokyo, Japan).

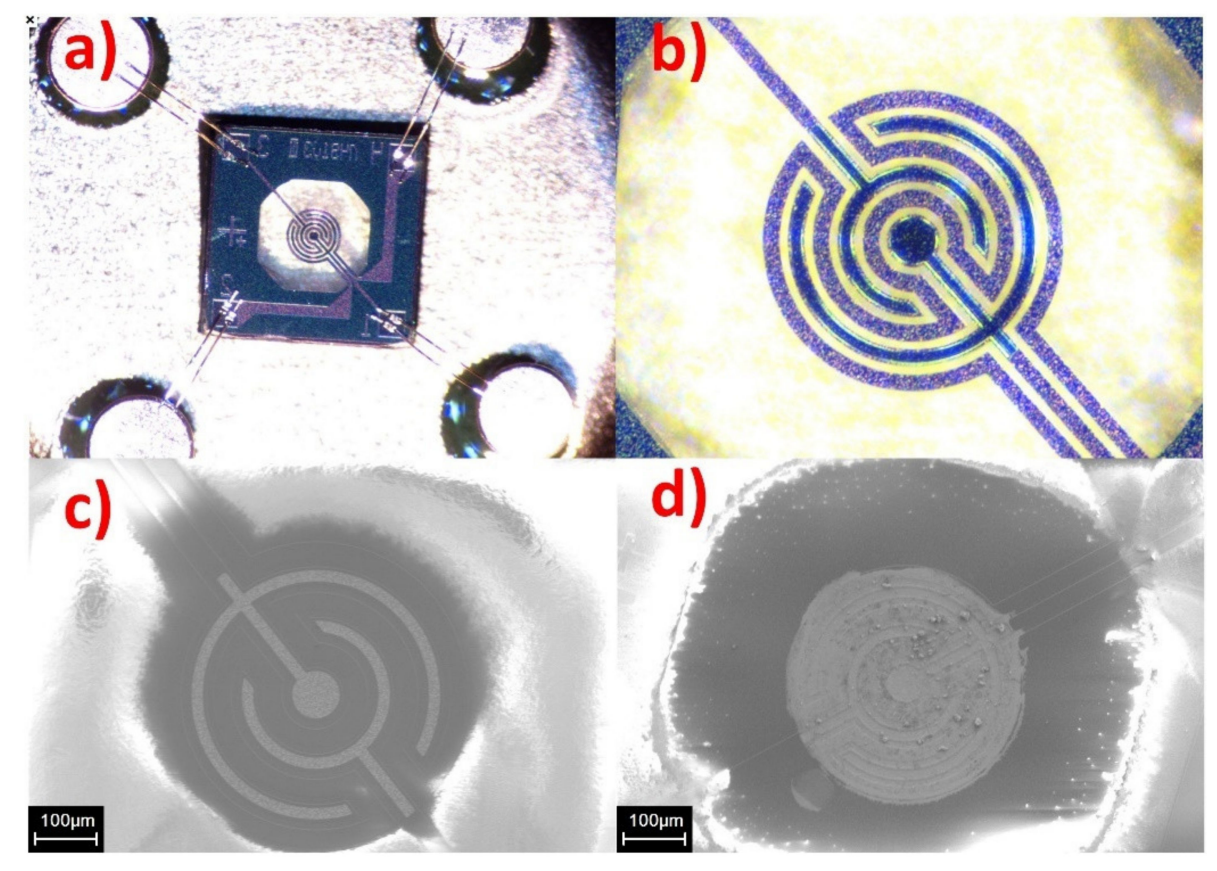

Figure 2. (a) Optical image of sensor MEMS crystal, fixed in TO-5 case; (b) close optical image of an insulating membrane, bearing a Pt micro-heater, electrically insulated from Pt interdigitated contacts; (c) SEM image of heated area with exposed Pt interdigitated contacts; (d) SEM image of heated area, uniformly covered by sensitive layer of La-1.5 material.

The gas sensitivity of the obtained materials in $\mathrm{CO}_{2}$ detection was studied in the 200-6700 ppm CO $\mathrm{CO}_{2}$ concentration range. The sensor response towards $\mathrm{H}_{2}(50 \mathrm{ppm}), \mathrm{CH}_{4}$ (100 ppm), $\mathrm{CO}(20 \mathrm{ppm}), \mathrm{NH}_{3}(20 \mathrm{ppm}), \mathrm{NO}$ (1 ppm), $\mathrm{NO}_{2}(1 \mathrm{ppm}), \mathrm{H}_{2} \mathrm{~S}$ (1 ppm) and $\mathrm{SO}_{2}$ (1 ppm) was determined as well in order to investigate the possible cross-sensitivity. The measurements were performed using constant flow air with a pre-assigned concentration of target gas through a gastight polytetrafluoroethylene (PTFE) sensor chamber. Pure air from the pure air generator (GChV 2.0, Himelektronika, Moscow, Russia) was used as a background gas. Due to the unavoidable presence of $\mathrm{CO}_{2}$ in generated pure air, in some cases, as mentioned in the text below, synthetic air with 2 ppm $\mathrm{CO}_{2}$ was used as background gas. Certified gas mixtures were used as the sources of target gases (Monitoring, St. Petersburg, Russia). Dilution was performed using precision mass gas flow controllers (Bronkhorst, Ruurlo, Netherlands). The measurements were carried out at different humidity conditions, which were pre-assigned and controlled by a P-2 gas flow humidifier (Cellkraft, Stockholm, Sweden). The sensor response $S=100 \% \times\left(R_{\mathrm{CO} 2}-R_{\text {air }}\right) / R_{\text {air }}$ was calculated as the difference in electrical resistance of the sensitive layer in the presence of target gas admixture $\left(R_{\mathrm{CO} 2}\right)$ and in clean air $\left(R_{a i r}\right)$, related to the resistance in clean air $\left(R_{\text {air }}\right)$ and multiplied by $100 \%$. 


\section{Results and Discussion}

\subsection{Materials Morphology and Phase Composition}

The obtained materials designations, parameters of synthesis, detected crystalline phases and surface area are summarized in Table 2.

Table 2. Obtained materials and their characteristics.

\begin{tabular}{cccccc}
\hline Material & $\mathbf{O}_{\mathbf{2}}$ Flow, L/min & Post-Synthetic Annealing & $\mathbf{S}_{\text {surf }}, \mathbf{~ m}^{\mathbf{2}} \mathbf{g}$ & Phase Composition, XRD & $\mathbf{I}_{\mathbf{3 6 1 0}} / \mathbf{I}_{\mathbf{1 4 8 3}}, \mathbf{F T I R}$ \\
\hline La-2 & 2 & - & 42 & $\mathrm{La}_{2} \mathrm{O}_{3}$ & 1.05 \\
La-2-500 & 2 & $500{ }^{\circ} \mathrm{C}, 24 \mathrm{~h}$ & 31 & $\mathrm{La}_{2} \mathrm{O}_{3}, \mathrm{La}(\mathrm{OH})_{3}$ & 2.12 \\
La-1.5 & 1.5 & - & 27 & $\mathrm{La}_{2} \mathrm{O}_{3}$ & \\
La-1.5-500 & 1.5 & $500{ }^{\circ} \mathrm{C}, 24 \mathrm{~h}$ & 27 & $\mathrm{La}_{2} \mathrm{O}_{3}, \mathrm{La}(\mathrm{OH})_{3}, \mathrm{LaO}(\mathrm{OH})$ & 5.12 \\
\hline
\end{tabular}

According to the XRD data, lanthanum oxide is the only crystalline phase, which is present in the as prepared materials after the FSP process (Figure 3). The $24 \mathrm{~h}$ annealing in the flow of dry pure air leads to the formation of lanthanum hydroxide. Additionally, in the case of La-1.5-500, some reflections, which may be referred to the formation of lanthanum oxyhydroxide, can be observed. All materials have a quite developed surface, which shrinks to some extent upon annealing in the case of La-2 material and stays the same in the case of material, obtained at the lower oxygen flow during spray formation. The grain size, calculated with the use of Scherrer formula, was 14-16 nm for all detected crystalline phases. SEM images (Figure 4) show that the powders are formed by agglomerates with a size of $30-70 \mathrm{~nm}$, and additional annealing at $500{ }^{\circ} \mathrm{C}$ does not lead to a change in the morphology and particle sizes.

The IR spectroscopy method turns out to be more informative for detecting amorphous phases that do not give a diffraction pattern. FTIR data (Figure 5) indicates the presence of lanthanum hydroxide in both as prepared and annealed materials that is reflected by the prominent bands at $3610 \mathrm{~cm}^{-1}$ and $645 \mathrm{~cm}^{-1}$, responsible for bulk OH stretching and bending, respectively [71]. The broad band with a maximum at $3433 \mathrm{~cm}^{-1}$, as well as the band at $1638 \mathrm{~cm}^{-1}$, indicate quite high water content in the obtained materials, which decreases to some extent upon $24 \mathrm{~h}$ annealing at $500{ }^{\circ} \mathrm{C}$. Notably, small absorption bands, related to symmetric and asymmetric stretching $\mathrm{C}-\mathrm{CH}_{2}$ and $\mathrm{C}-\mathrm{CH}_{3}$ oscillations $\left(2964-2861 \mathrm{~cm}^{-1}\right)$, are observed in as prepared samples, indicating some residual hydrocarbon content due to incomplete combustion of organic matter, specifically precursor and fuel components.

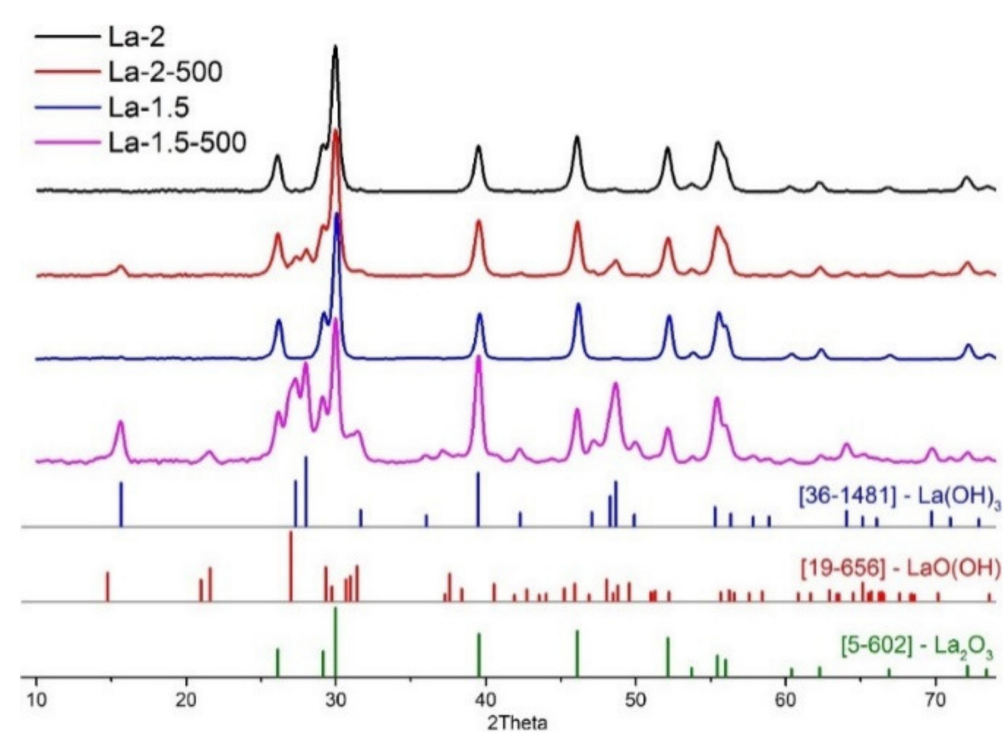

Figure 3. XRD patterns of obtained materials. 

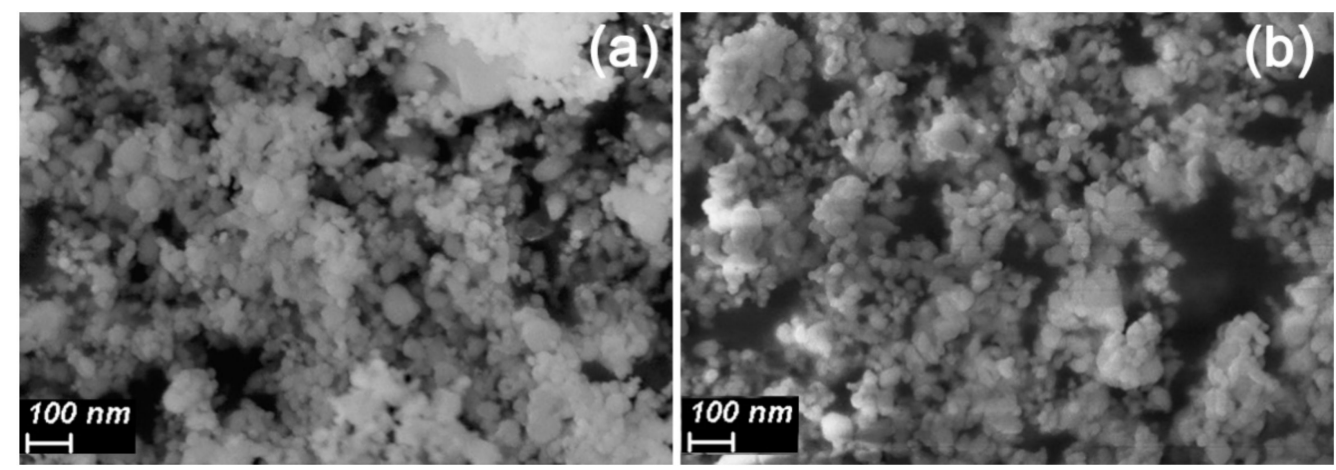

Figure 4. SEM images of La-1.5 (a) and La-1.5-500 (b) materials.

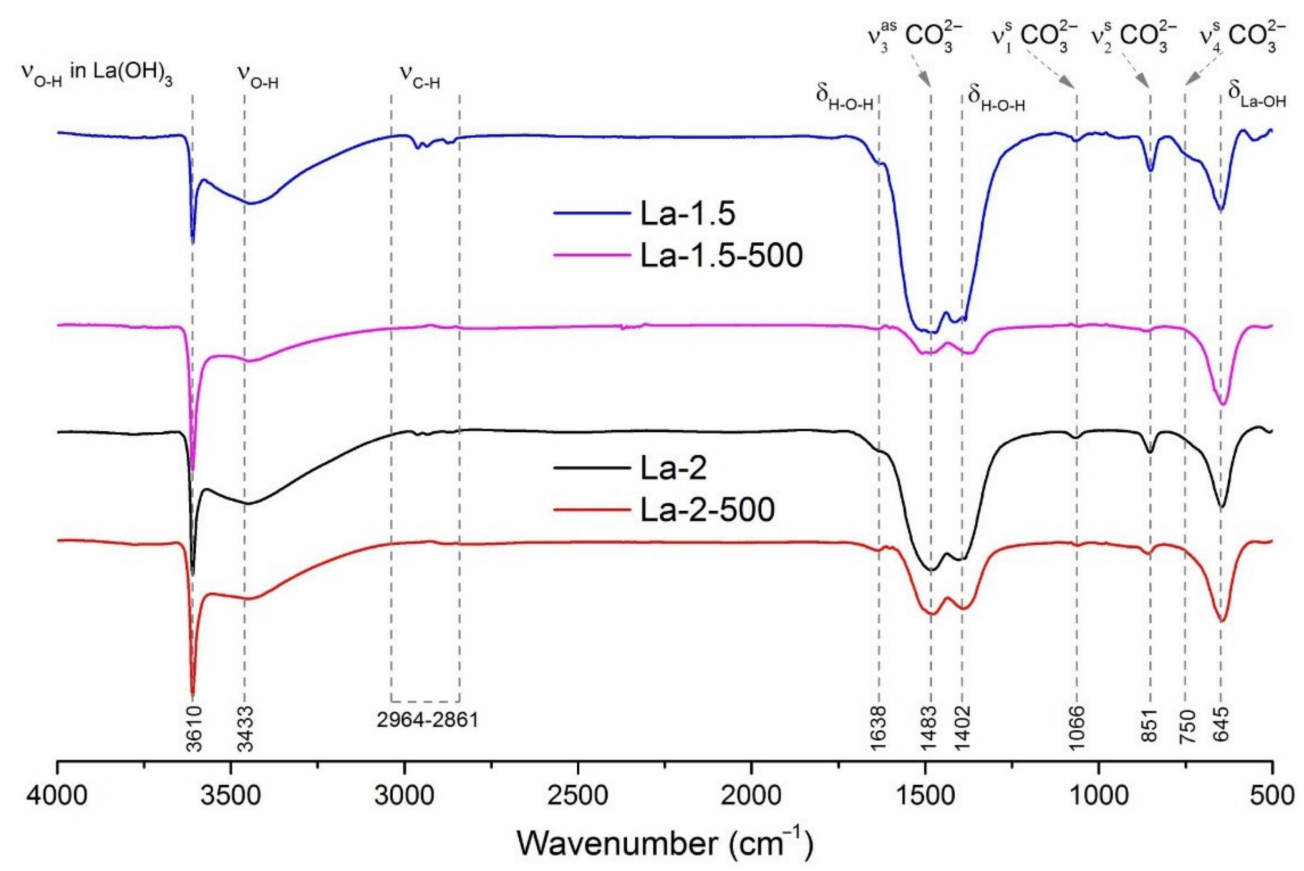

Figure 5. FTIR spectra of obtained materials.

The bands at $1483,1066,851$ and $750 \mathrm{~cm}^{-1}$ are related to the carbonate anion vibrations $v_{3}, v_{1}, v_{2}$ and $v_{4}$ respectively, while the absorption maximum at ca. $1402 \mathrm{~cm}^{-1}$ may be related to the bending vibrational mode of chemisorbed water molecules [72]. The observed spectra reflect the formation of lanthanum carbonate and oxycarbonate phases during FSP process. These absorption bands significantly decrease in intensity after materials annealing at $500{ }^{\circ} \mathrm{C}$. The ratio $\mathrm{I}_{3610} / \mathrm{I}_{1483}$ of vibration intensities at $3610 \mathrm{~cm}^{-1}$ (hydroxyl groups) and at $1483 \mathrm{~cm}^{-1}$ (carbonate groups) reflects the relative content of carbonatecontaining phases in synthesized samples (Table 2). It is obvious that the La-1.5 sample obtained at lower oxygen flow in FSP process is characterized by a higher concentration of carbon-containing phases. Annealing at $500{ }^{\circ} \mathrm{C}$ leads to a decrease in the relative content of carbonate and oxycarbonate species. The simultaneous appearance of the $\mathrm{La}(\mathrm{OH})_{3}$ and $\mathrm{LaOOH}$ phases observed by XRD (Table 2) indicates the process of high-temperature hydrolysis of carbonate particles by water vapor.

\subsection{Gas Sensor Properties}

In the presence of $\mathrm{CO}_{2}$, the resistance of the samples increases and returns to the initial value in pure air (Figure 6) in accordance to previously observed by other researchers [69]. 


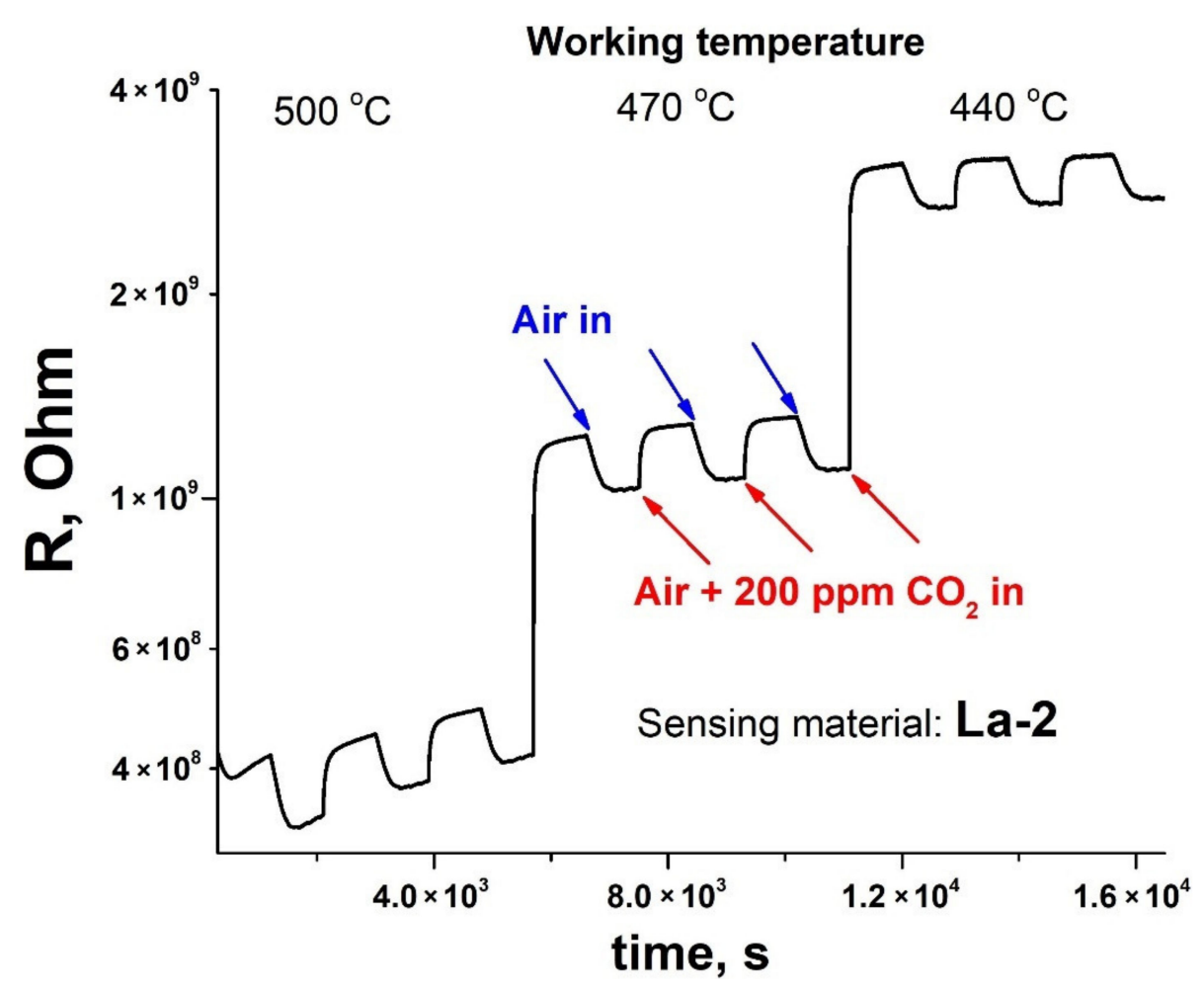

Figure 6. Electrical resistance transient of La-2 material at different working temperatures in the flow of generated dry air and in the flow of air with admixture of 200 ppm $\mathrm{CO}_{2}$ above background (a.b.).

The temperature dependence of the sensor response towards $\mathrm{CO}_{2}$ demonstrates maximum at $470{ }^{\circ} \mathrm{C}$, which is shifted down to $410{ }^{\circ} \mathrm{C}$ with the increase in air relative humidity (Figure 7). In can be noted that the response increase with the growth of the ambient humidity is most prominent in the range below 30\% RH (Figure 8a). Above this level the further humidity increase is associated with minimal signal rise and in the case of La-1.5 material the response stays nearly constant. The dependence of the sensor response on the $\mathrm{CO}_{2}$ concentration is in agreement with power law, typical for semiconductor gas sensitive metal oxides (Figure 8b) [73]. It demonstrates good linearity in double logarithmic coordinates in a quite wide range of concentrations between $200 \mathrm{ppm}$ up to $0.67 \%$ above the background level of $\mathrm{CO}_{2}$.

Among the obtained materials, the La-1.5 sample demonstrated the best performance, so further studies were focused on it. The cross-sensitivity of this material to the other components in concentrations relevant to atmospheric air monitoring can be considered quite low (Figure 9).
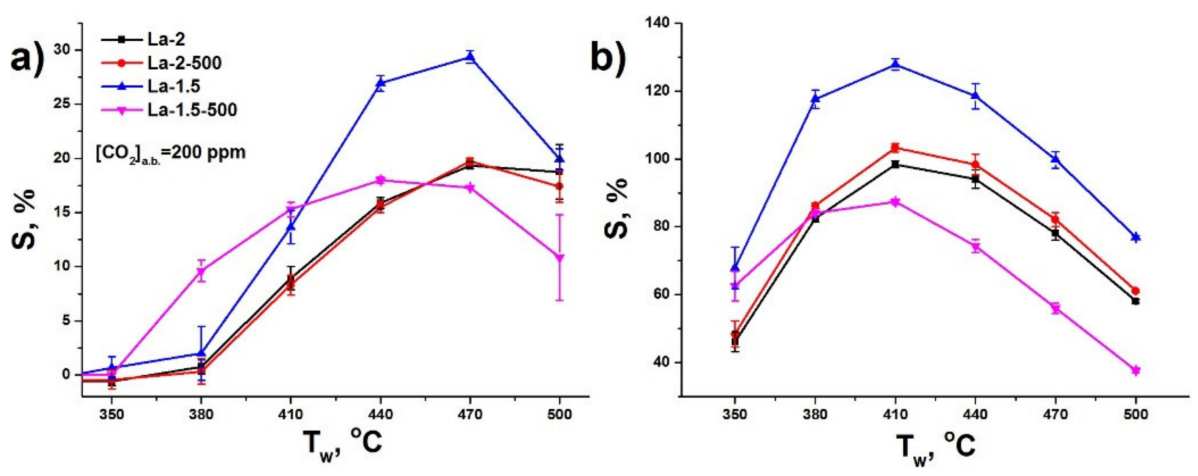

Figure 7. The temperature dependence of sensor response towards $200 \mathrm{ppm} \mathrm{CO}_{2}$ above background (a.b.) (a) in dry air; (b) at 30\% relative humidity (at room temperature). 

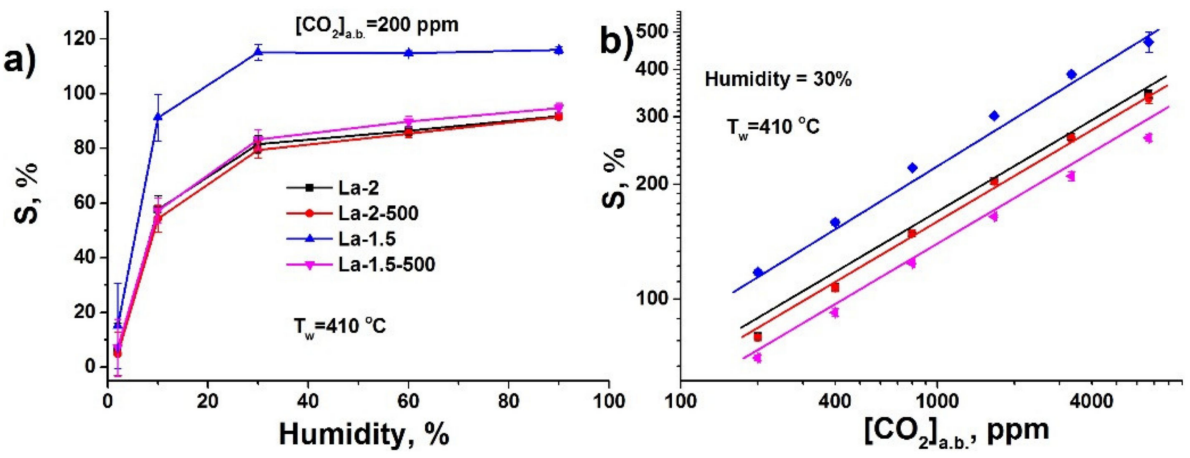

Figure 8. (a) Sensor response towards $200 \mathrm{ppm} \mathrm{CO}$ above background (a.b.) in generated air with different relative humidity (working temperature $410{ }^{\circ} \mathrm{C}$ ); (b) Sensor response vs. $\mathrm{CO}_{2}$ concentration above background (a.b.) in generated air (relative humidity $30 \%$, working temperature $410{ }^{\circ} \mathrm{C}$ ).

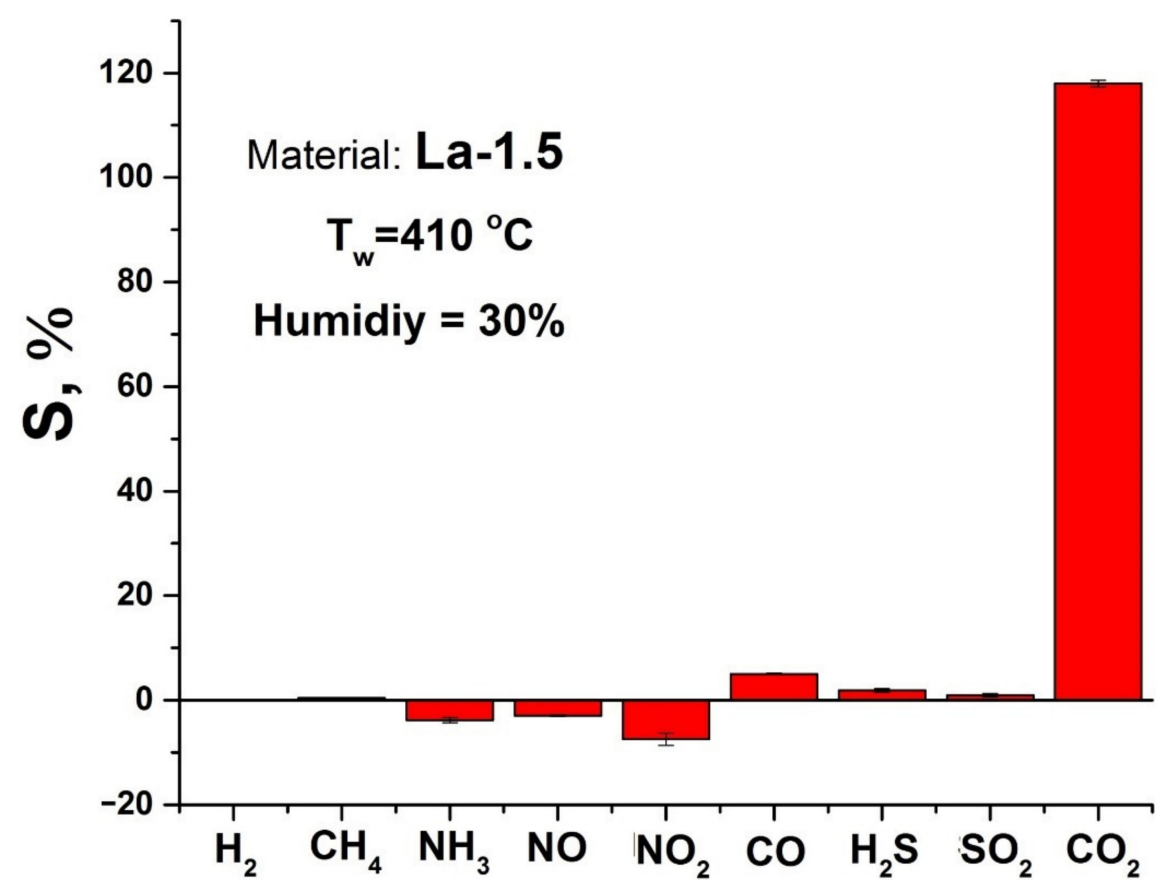

Figure 9. Cross-response of La-1.5 material towards $\mathrm{H}_{2}$ (50 ppm), $\mathrm{CH}_{4}(100 \mathrm{ppm}), \mathrm{NH}_{3}(20 \mathrm{ppm})$, $\mathrm{NO}(1 \mathrm{ppm}), \mathrm{NO}_{2}$ (1 ppm), $\mathrm{CO}(20 \mathrm{ppm}), \mathrm{H}_{2} \mathrm{~S}$ (1 ppm) and $\mathrm{SO}_{2}$ (1 ppm) in comparison with the response to $\mathrm{CO}_{2}(200 \mathrm{ppm})$. Working temperature $410{ }^{\circ} \mathrm{C}$, relative humidity $30 \%$.

The most prominent cross-response is obtained in the case of nitrogen dioxide, however, it has a negative sign, as this gas possesses oxidative properties. Its adsorption on the materials surface leads to the decrease in free electron density and increase in the $p$-type conductivity. A similar phenomenon is observed in the case of NO. Although, this gas is a reducing one, its interaction with the sensitive layer at elevated temperatures leads to formation of $\mathrm{NO}_{2}$ molecules, which is mediated by oxygen on the surface of semiconductor oxide [74].

$$
2 \mathrm{NO}+\mathrm{O}_{2 \mathrm{ads}} \rightarrow 2 \mathrm{NO}_{2}
$$

Adsorption of this newly formed $\mathrm{NO}_{2}$ dominates the formation of sensor response. The negative sensor response, observed in the case of ammonia may also be due to formation of nitrogen dioxide during $\mathrm{NH}_{3}$ oxidation on the metal oxide surface.

$$
\mathrm{NH}_{3}+\mathrm{O}_{2 \text { ads }} \rightarrow 2 \mathrm{NO}_{2}+3 \mathrm{H}_{2} \mathrm{O}
$$


The highest positive sensor cross-response is observed in the case of $\mathrm{CO}$, which is obviously due to oxidation of this adsorbed molecule into $\mathrm{CO}_{2}$ with the further sensor process.

$$
2 \mathrm{CO}+\mathrm{O}_{2 \mathrm{ads}} \rightarrow 2 \mathrm{CO}_{2}
$$

The comparison of the concentration dependence of the sensor signal towards $\mathrm{CO}_{2}, \mathrm{ob}-$ tained in the generated pure air and synthetic air without $\mathrm{CO}_{2}$ background concentrations, reveals almost two-fold improvement of response in the latter case (Figure 10a).
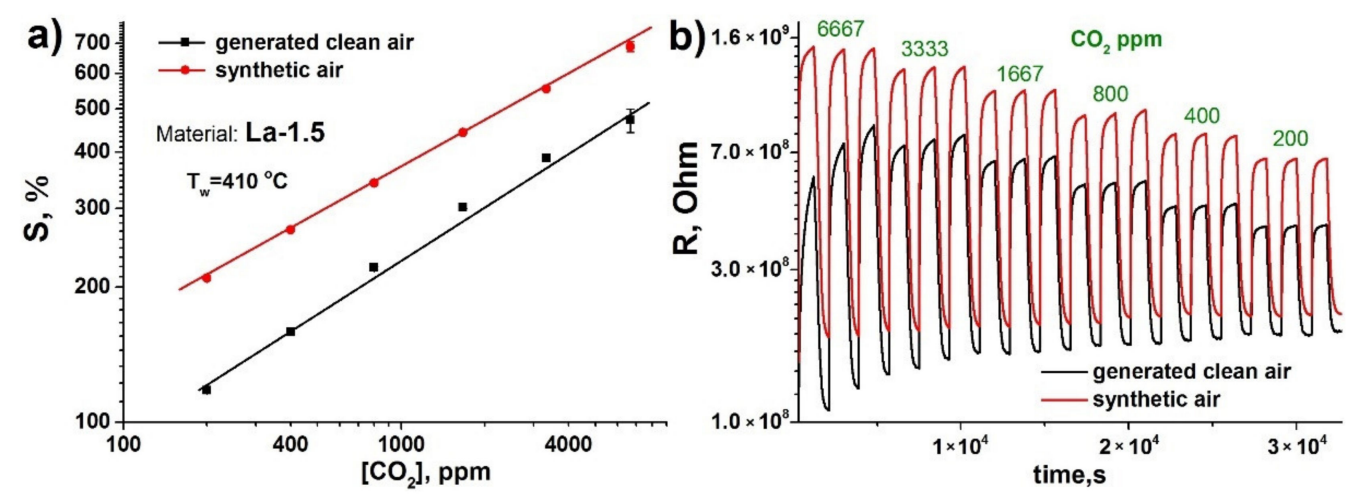

Figure 10. (a) Sensor response of La-1.5 material vs. $\mathrm{CO}_{2}$ concentration in generated and synthetic air; (b) dynamic response of La-1.5 material towards different $\mathrm{CO}_{2}$ concentrations in generated and synthetic air. Working temperature $410{ }^{\circ} \mathrm{C}$, relative humidity $30 \%$.

Moreover, the distinctive rise of the baseline resistance of the material in the flow of generated air can be observed (Figure 10b). These phenomena can be attributed to the presence of the unaccounted amounts of nitrogen oxides in the generated air, as the air generator purifies air only from particulate matter, humidity (below $10 \mathrm{ppm}$ at the outlet) and organic compounds (total organic matter content below $0.1 \mathrm{ppm}$ ). The adsorption of nitrogen dioxide on the materials surface not only leads to the decrease of the sensitive layer electrical resistance, but also hampers the adsorptive interaction with $\mathrm{CO}_{2}$, decreasing the response. Given the observed background response level, the lower $\mathrm{CO}_{2}$ detection limit was calculated at 3.5 and 2.5 ppm for generated air and synthetic air, respectively.

To clarify the mechanism of the sensor response and to assess the reversibility of the interaction of $\mathrm{CO}_{2}$ with the surface of the sensitive material, an operando DRIFT spectroscopy study was effectuated. The experiments were carried out at $410{ }^{\circ} \mathrm{C}$, corresponding to the temperature of sensor measurements, in humidified generated air $(\mathrm{RH}=70 \%)$ with or without 400 ppm $\mathrm{CO}_{2}$. The DRIFT spectra in the range of $3750-3100 \mathrm{~cm}^{-1}$, corresponding to the oscillations of hydroxyl groups, and $1700-800 \mathrm{~cm}^{-1}$, corresponding to the oscillations of various carbonate species, are shown in Figure 11. In the $3750-3100 \mathrm{~cm}^{-1}$ range there is a sharp band at $3590 \mathrm{~cm}^{-1}$ corresponding to the oscillations of isolated hydroxyl groups on lanthanum hydroxide surface. The negative intensity of this band indicates a decrease in the concentration of $\mathrm{OH}$ groups. This may be due to hydroxyls recombination and desorption at a temperature of $410{ }^{\circ} \mathrm{C}$ even in a humid atmosphere. In the $1700-800 \mathrm{~cm}^{-1}$ range one can observe the positive bands corresponding to monodentate $\left(1520\right.$ and $\left.853 \mathrm{~cm}^{-1}\right)$ and bidentate $\left(1285 \mathrm{~cm}^{-1}\right)$ surface carbonate species, respectively [69]. A sharp band at $1085 \mathrm{~cm}^{-1}$ can be assigned to carbonate group of lanthanum oxycarbonate [71].

Figure 12 demonstrates the change in intensities of 3590, 1520 and $1285 \mathrm{~cm}^{-1}$ bands depending on exposure time in different gas atmosphere. We can conclude the hydroxyls concentration is mainly determined by the exposure time at $410{ }^{\circ} \mathrm{C}$ but practically does not depend on the presence of $\mathrm{CO}_{2}$ in the gas phase. In addition to the main trend, the intensity of $\mathrm{OH}$ vibrations decreases slightly with the introduction of $\mathrm{CO}_{2}$, and also increases slightly with subsequent exposure in the air. This indicates the replacement of some hydroxyls by adsorbed carbonates due to competitive adsorption [69]. In general, the concentration of hydroxyls approaches a stationary value for two hours at $410{ }^{\circ} \mathrm{C}$. On 
the contrary, the intensities of carbonate peaks strongly depend on the composition of the gas phase: their intensities increase in the presence of $\mathrm{CO}_{2}$, and then decrease with subsequent exposure in the air. The main difference in the behavior of surface bidentate carbonates (band at $1285 \mathrm{~cm}^{-1}$ ) and monodentate carbonates (band at $1590 \mathrm{~cm}^{-1}$ ) is that the former are completely desorbed when $\mathrm{CO}_{2}$ is removed from the atmosphere, and the latter are partially preserved on the surface. Such a reorganization of the surface adsorbed groups allows us to expect that preliminary artificial aging in a humid atmosphere with a high concentration of $\mathrm{CO}_{2}$ at a temperature of about $400{ }^{\circ} \mathrm{C}$ will lead to sufficient longterm stability of sensor characteristics necessary for the sensors integration into GHG monitoring system.

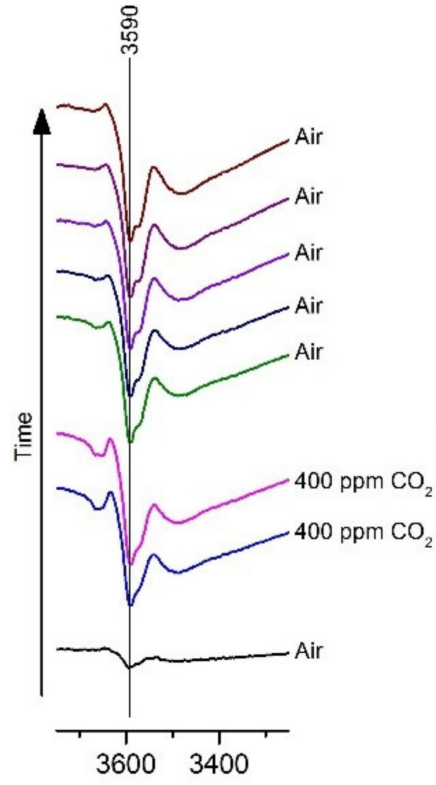

Wavenumber, $\mathrm{cm}^{-1}$

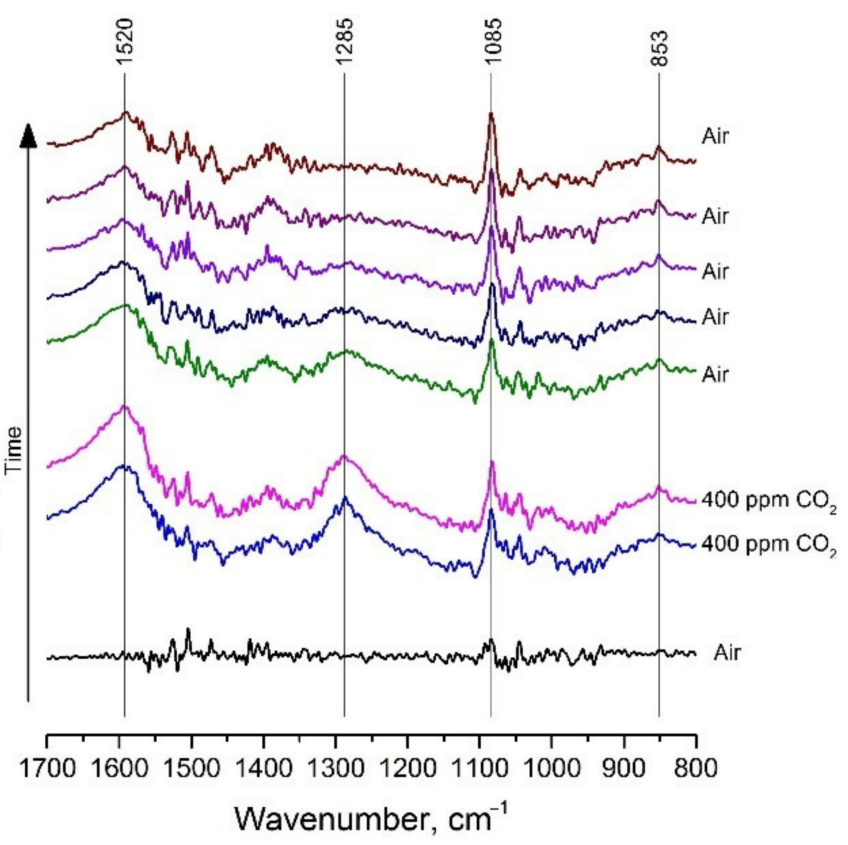

Wavenumber, $\mathrm{cm}^{-1}$

Figure 11. Evolution of DRIFT spectra of La-1.5 material at $410{ }^{\circ} \mathrm{C}$ in humidified generated air $(\mathrm{RH}=70 \%)$ with or without 400 ppm $\mathrm{CO}_{2}$.

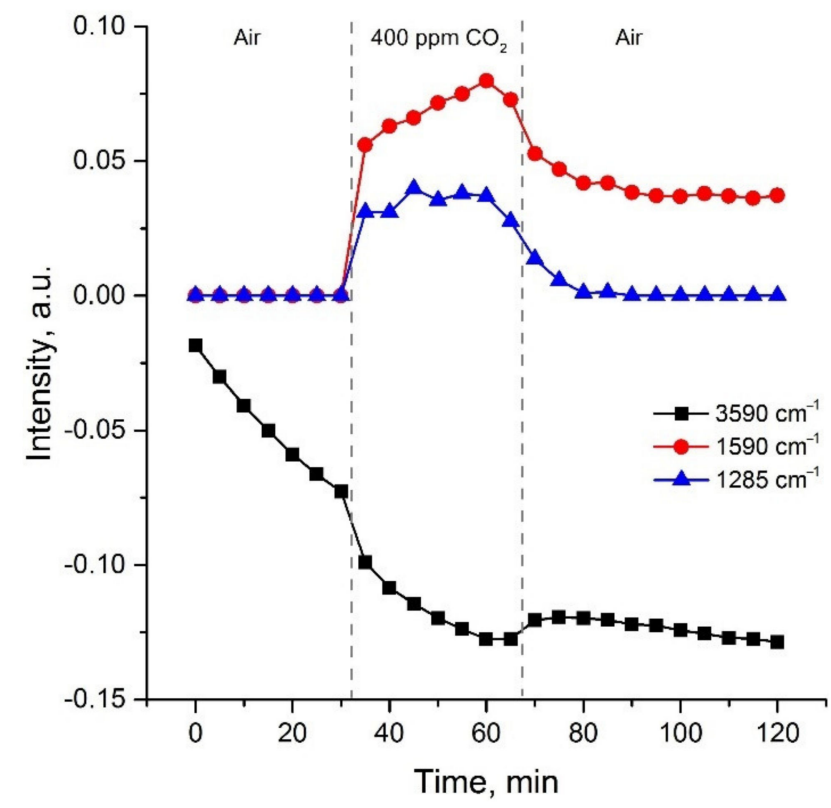

Figure 12. Change in intensities of 3590, 1520 and $1285 \mathrm{~cm}^{-1}$ bands depending on exposure time in different gas atmosphere. 


\section{Conclusions}

Flame spray pyrolysis technique allows to obtain fine particulate composite material with a dominating $\mathrm{La}_{2} \mathrm{O}_{3}$ crystalline phase, accompanied with amorphous $\mathrm{La}(\mathrm{OH})_{3}$ and carbonates. Increase in the carbonate phase content, which can be achieved through oxygendeficit synthesis conditions, leads to the increase in the composite response towards $\mathrm{CO}_{2}$. Combination of low $\mathrm{CO}_{2}$ detection limit with sensor response independence from air humidity at $\mathrm{RH}>30 \%$ observed for the obtained $\mathrm{La}_{2} \mathrm{O}_{3}$-based nanocomposite makes it suitable for detecting $\mathrm{CO}_{2}$ in atmospheric air at the current concentration level (400 ppm) and below. Semiconductor sensors, based on low power consuming and cost-effective MEMS micro-hotplates with a sensitive layer of synthesized $\mathrm{La}_{2} \mathrm{O}_{3}$-based nanocomposite, are promising elements for creating distributed networks with high spatial and temporal resolution for the GHG monitoring system.

Author Contributions: Conceptualization, V.K., M.R. and O.Z.; methodology, V.K., S.P. and V.A.; formal analysis, M.A., V.P. and V.K.; Investigation, M.A., V.P., D.F., S.G. and A.N.; data curation, M.A., V.P., V.K. and M.R.; writing—original draft preparation, V.K., E.G. and M.R.; writing—review and editing, V.K., E.G., M.R. and O.Z.; supervision, M.R. All authors have read and agreed to the published version of the manuscript.

Funding: This research was funded by Russian Science Foundation, grant number 19-13-00245.

Institutional Review Board Statement: Not applicable.

Informed Consent Statement: Not applicable.

Data Availability Statement: Not applicable.

Acknowledgments: FTIR and DRIFT experiments were carried out using the equipment purchased by funds of Lomonosov Moscow State University Program of the Development. The authors acknowledge support from the "Nanochemistry and Nanomaterials" MSU Equipment Center acting under Lomonosov Moscow State University Program of Development.

Conflicts of Interest: The authors declare no conflict of interest.

\section{References}

1. Pearson, P.N.; Palmer, M.R. Atmospheric carbon dioxide concentrations over the past 60 million years. Nature 2000, 406, 695-699. [CrossRef]

2. Rae, J.W.B.; Zhang, Y.G.; Liu, X.Q.; Foster, G.L.; Stoll, H.M.; Whiteford, R.D.M. Atmospheric $\mathrm{CO}_{2}$ over the past 66 million years from marine archives. Annu. Rev. Earth Plant. Sci. 2021, 49, 609-641. [CrossRef]

3. Tong, D.; Zhang, Q.; Zheng, Y.X.; Caldeira, K.; Shearer, C.; Hong, C.P.; Qin, Y.; Davis, S.J. Committed emissions from existing energy infrastructure jeopardize 1.5 degrees $C$ climate target. Nature 2019, 572, 373-377. [CrossRef] [PubMed]

4. Pendrill, F.; Persson, U.M.; Godar, J.; Kastner, T.; Moran, D.; Schmidt, S.; Wood, R. Agricultural and forestry trade drives large share of tropical deforestation emissions. Glob. Environ. Chang. 2019, 56, 1-10. [CrossRef]

5. Mitchell, J.F.B.; Johns, T.C.; Ingram, W.J.; Lowe, J.A. The effect of stabilising atmospheric carbon dioxide concentrations on global and regional climate change. Geophys. Res. Lett. 2000, 27, 2977-2980. [CrossRef]

6. Fuglestvedt, J.S.; Masson-Delmotte, V.; Zhai, P.; Pirani, A.; Fuglestvedt, J.S.; Masson-Delmotte, V.; Zhai, P.; Pirani, A. Towards the sixth assessment report of the intergovernmental panel on climate change (IPCC). AGUFM 2016, 2016, U14A-02.

7. IEA. Global Energy Review. 2021. Available online: https://www.iea.org/reports/global-energy-review-2021 (accessed on 21 September 2021).

8. IEA. $\mathrm{CO}_{2}$ Emissions-Global Energy Review 2021-Analysis. Available online: https://www.iea.org/reports/global-energyreview-2021/co2-emissions (accessed on 21 September 2021).

9. Paris Agreement. Available online: https://unfccc.int/sites/default/files/english_paris_agreement.pdf (accessed on 21 September 2021).

10. Statistical Review of World Energy 2020, 69th Edition. Available online: https://www.bp.com/content/dam/bp/businesssites/en/global/corporate/pdfs/energy-economics/statistical-review/bp-stats-review-2020-full-report.pdf (accessed on 21 September 2021).

11. Statistical Review of World Energy 2021, 70th Ed. Available online: https://www.bp.com/content/dam/bp/businesssites/en/global/corporate/pdfs/energy-economics/statistical-review/bp-stats-review-2021-full-report.pdf (accessed on 21 September 2021). 
12. IEA. Net Zero by 2050-A Roadmap for the Global Energy Sector. Available online: https://www.iea.org/reports/net-zero-by2050 (accessed on 21 September 2021).

13. IEA. World Energy Outlook 2020-Analysis. Available online: https:/ /www.iea.org/reports/world-energy-outlook-2020 (accessed on 21 September 2021).

14. Carbon Dioxide Emissions Embodied in International Trade-OECD. Available online: https://www.oecd.org/sti/ind/ carbondioxideemissionsembodiedininternationaltrade.htm (accessed on 21 September 2021).

15. Regulation (Eu) 2021/1119 of the European Parliament and of the Council. Available online: https:/ / eur-lex.europa.eu/legalcontent/EN/TXT / ?uri=CELEX\%3A32021R1119\&qid=1632217752018 (accessed on 21 September 2021).

16. Bravkov, P.V.; Durdyeva, A.A.; Zhdaneev, O.V.; Zuev, S.S.; Korenev, V.V.; Frolov, K.N.; Chuboksarov, V.S. Technical Policy Issues of the Fuel and Energy Complex of the Russian Federation; Zhdaneev, O.V., Ed.; Nauka: Moscow, Russia, 2020; p. 304.

17. EIB Project Carbon Footprint Methodologies. Available online: https://www.eib.org/attachments/strategies/eib_project_ carbon_footprint_methodologies_en.pdf (accessed on 21 September 2021).

18. Greenhouse Gas Assessment Emissions Methodology Publications. Available online: https://publications.iadb.org/publications/ english/document/Greenhouse-Gas-Assessment-Emissions-Methodology.pdf (accessed on 21 September 2021).

19. IPCC National Greenhouse Gas Inventories Programme. Available online: https://www.ipcc-nggip.iges.or.jp/support/Primer_ 2006GLs.pdf (accessed on 21 September 2021).

20. Antolín, D.; Medrano, N.; Calvo, B.; Pérez, F. A wearable wireless sensor network for indoor smart environment monitoring in safety applications. Sensors 2017, 17, 365. [CrossRef]

21. Delebarre, C.; Pujolle, T.; Cousin, G.; Domon, A.; Froux, J.; Jourdan, J. Wireless low cost $\mathrm{CO}_{2}$ monitoring system design and evaluation using non dispersive infrared sensor. Wirel. Sens. Netw. 2018, 10, 119-130. [CrossRef]

22. Lohani, D.; Acharya, D. Real time in-vehicle air quality monitoring using mobile sensing. In Proceedings of the 2016 IEEE Annual India Conference (INDICON), Bangalore, India, 16-18 December 2016. [CrossRef]

23. Jin, M.; Liu, S.; Schiavon, S.; Spanos, C. Automated mobile sensing: Towards high-granularity agile indoor environmental quality monitoring. Build. Environ. 2018, 127, 268-276. [CrossRef]

24. IEA. Greenhouse Gas Emissions from Energy: Overview-Analysis. Available online: https://www.iea.org/reports/greenhousegas-emissions-from-energy-overview (accessed on 21 September 2021).

25. Noumonvi, K.D.; Ferlan, M.; Eler, K.; Alberti, G.; Peressotti, A.; Cerasoli, S. Estimation of carbon fluxes from eddy covariance data and satellite-derived vegetation indices in a karst grassland (Podgorski Kras, Slovenia). Remote Sens. 2019, 11, 649. [CrossRef]

26. Lin, C.; Thomson, G.; Popescu, S.C. An IPCC-compliant technique for forest carbon stock assessment using airborne LiDARderived tree metrics and competition index. Remote Sens. 2016, 8, 528. [CrossRef]

27. Predictors of Measurement Accuracy in the Remote Sensing of $\mathrm{CO}_{2}$ Emissions. Available online: https://www3.epa.gov/ttnchie1 / conference/ei20/session7/dwinters.pdf (accessed on 21 September 2021).

28. Gautam, Y.K.; Sharma, K.; Tyagi, S.; Ambedkar, A.K.; Chaudhary, M.; Singh, B.P. Nanostructured metal oxide semiconductorbased sensors for greenhouse gas detection: Progress and challenges. R. Soc. Open Sci. 2021, 8, 201324. [CrossRef]

29. Mallia, D.V.; Mitchell, L.E.; Kunik, L.; Fasoli, B.; Bares, R.; Gurney, K.R.; Mendoza, D.L.; Lin, J.C. Constraining urban CO 2 emissions using mobile observations from a light rail public transit platform. Environ. Sci. Technol. 2020, 54, 15613-15621. [CrossRef]

30. Berman, E.S.F.; Fladeland, M.; Liem, J.; Kolyer, R.; Gupta, M. Greenhouse gas analyzer for measurements of carbon dioxide, methane, and water vapor aboard an unmanned aerial vehicle. Sens. Actuators B 2012, 169, 128-135. [CrossRef]

31. Zenevich, S.; Gazizov, I.; Churbanov, D.; Plyashkov, Y.; Spiridonov, M.; Talipov, R.; Rodin, A. A concept of 2U spaceborne multichannel heterodyne spectroradiometer for greenhouse gases remote sensing. Remote Sens. 2021, 13, 2235. [CrossRef]

32. Suzuki, T.; Sackmann, A.; Oprea, A.; Weimar, U.; Barsan, N. Chemoresistive $\mathrm{CO}_{2}$ gas sensors based on $\mathrm{La}_{2} \mathrm{O}_{2} \mathrm{CO}_{3}$ : Sensing mechanism insights provided by operando characterization. ACS Sens. 2020, 5, 2555-2562. [CrossRef] [PubMed]

33. Collier-Oxandale, A.; Casey, J.G.; Piedrahita, R.; Ortega, J.; Halliday, H.; Johnston, J.; Hannigan, M.P. Assessing a low-cost methane sensor quantification system for use in complex rural and urban environments. Atmos. Meas. Tech. 2018, 11, 3569-3594. [CrossRef] [PubMed]

34. Smith, K.R.; Edwards, P.M.; Evans, M.J.; Lee, J.D.; Shaw, M.D.; Squires, F.; Wilde, S.; Lewis, A.C. Clustering approaches to improve the performance of low cost air pollution sensors. Faraday Discuss. 2017, 200, 621-637. [CrossRef] [PubMed]

35. Collier-Oxandale, A.M.; Thorson, J.; Halliday, H.; Milford, J.; Hannigan, M. Understanding the ability of low-cost MOx sensors to quantify ambient VOCs. Atmos. Meas. Tech. 2019, 12, 1441-1460. [CrossRef]

36. Weissert, L.F.; Alberti, K.; Miskell, G.; Pattinson, W.; Salmond, J.A.; Henshaw, G.; Williams, D.E. Low-cost sensors and microscale land use regression: Data fusion to resolve air quality variations with high spatial and temporal resolution. Atmos. Environ. 2019, 213, 285-295. [CrossRef]

37. Moltchanov, S.; Levy, I.; Etzion, Y.; Lerner, U.; Broday, D.M.; Fishbain, B. On the feasibility of measuring urban air pollution by wireless distributed sensor networks. Sci. Total Environ. 2015, 502, 537-547. [CrossRef] [PubMed]

38. Spinelle, L.; Gerboles, M.; Villani, M.G.; Aleixandre, M.; Bonavitacola, F. Field calibration of a cluster of low-cost commercially available sensors for air quality monitoring. Part B: NO, CO and $\mathrm{CO}_{2}$. Sens. Actuators B Chem. 2017, 238, 706-715. [CrossRef]

39. Spinelle, L.; Gerboles, M.; Villani, M.G.; Aleixandre, M.; Bonavitacola, F. Field calibration of a cluster of low-cost available sensors for air quality monitoring. Part A: Ozone and nitrogen dioxide. Sens. Actuators B Chem. 2015, 215, 249-257. [CrossRef] 
40. Borrego, C.; Ginja, J.; Coutinho, M.; Ribeiro, C.; Karatzas, K.; Sioumis, T.; Katsifarakis, N.; Konstantinidis, K.; De Vito, S.; Esposito, E.; et al. Assessment of air quality microsensors versus reference methods: The EuNetAir joint exercise-part II. Atmos. Environ. 2018, 193, 127-142. [CrossRef]

41. Borrego, C.; Costa, A.M.; Ginja, J.; Amorim, M.; Coutinho, M.; Karatzas, K.; Sioumis, T.; Katsifarakis, N.; Konstantinidis, K.; De Vito, S.; et al. Assessment of air quality microsensors versus reference methods: The EuNetAir joint exercise. Atmos. Environ. 2016, 147, 246-263. [CrossRef]

42. Michel, C.R.; Lopez Contreras, N.L.; Martinez Preciado, A.H. $\mathrm{CO}_{2}$ and $\mathrm{CO}$ gas sensing properties of nanostructured BiOCl ribbons doped with gold nanoparticles. Sens. Actuators B Chem. 2012, 173, 100-105. [CrossRef]

43. Deepa, S.; Prasanna Kumari, K.; Thomas, B. Contribution of oxygen-vacancy defect-types in enhanced $\mathrm{CO}_{2}$ sensing of nanoparticulate $\mathrm{Zn}$-doped $\mathrm{SnO}_{2}$ films. Ceram. Int. 2017, 43, 17128-17141. [CrossRef]

44. Xiong, Y.; Xue, Q.; Ling, C.; Lu, W.; Ding, D.; Zhu, L.; Li, X. Effective $\mathrm{CO}_{2}$ detection based on LaOCl-doped SnO ${ }_{2}$ nanofibers: Insight into the role of oxygen in carrier gas. Sens. Actuators B Chem. 2017, 241, 725-734. [CrossRef]

45. Jeong, Y.J.; Balamurugan, C.; Lee, D.W. Enhanced $\mathrm{CO}_{2}$ gas-sensing performance of $\mathrm{ZnO}$ nanopowder by la loaded during simple hydrothermal method. Sens. Actuators B Chem. 2016, 229, 288-296. [CrossRef]

46. Hunge, Y.M.; Yadav, A.A.; Kulkarni, S.B.; Mathe, V.L. A multifunctional ZnO thin film based devises for photoelectrocatalytic degradation of terephthalic acid and $\mathrm{CO}_{2}$ gas sensing applications. Sens. Actuators B Chem. 2018, 274, 1-9. [CrossRef]

47. Aboud, A.A.; Al-Kelesh, H.; Rouby, W.M.A.E.; Farghali, A.A.; Hamdedein, A.; Khedr, M.H. $\mathrm{CO}_{2}$ responses based on pure and doped $\mathrm{CeO}_{2}$ nanopellets. J. Mater. Res. Technol. 2018, 7, 14-20. [CrossRef]

48. Colak, H.; Karaköse, E. Synthesis and characterization of different dopant (Ge, Nd, W)-doped $\mathrm{ZnO}$ nanorods and their $\mathrm{CO}_{2}$ gas sensing applications. Sens. Actuators B Chem. 2019, 296, 126629. [CrossRef]

49. Ding, D.; Lu, W.; Xiong, Y.; Pan, X.; Zhang, J.; Ling, C.; Du, Y.; Xue, Q. Facile synthesis of $\mathrm{La}_{2} \mathrm{O}_{2} \mathrm{CO}_{3}$ nanoparticle films and its $\mathrm{CO}_{2}$ sensing properties and mechanisms. Appl. Surf. Sci. 2017, 426, 725-733. [CrossRef]

50. Juang, F.R.; Chen, B.Y. Effect of adding ZHS microcubes on $\mathrm{ZnO}$ nanorods for $\mathrm{CO}_{2}$ gas sensing applications. Solid. State. Electron. 2020, 164, 107711. [CrossRef]

51. Hsu, K.C.; Fang, T.H.; Hsiao, Y.J.; Chan, C.A. Highly response $\mathrm{CO}_{2}$ gas sensor based on $\mathrm{AuLa}_{2} \mathrm{O}_{3}$ doped SnO $\mathrm{O}_{2}$ nanofibers. Mater Lett. 2020, 261, 127144. [CrossRef]

52. Wang, D.; Chen, Y.; Liu, Z.; Li, L.; Shi, C.; Qin, H.; Hu, J. $\mathrm{CO}_{2}$-sensing properties and mechanism of nano-SnO ${ }_{2}$ thick-film sensor. Sens. Actuators B Chem. 2016, 227, 73-84. [CrossRef]

53. Kim, M.Y.; Choi, Y.N.; Bae, J.M.; Oh, T.S. Carbon dioxide sensitivity of La-doped thick film tin oxide gas sensor. Ceram. Int. 2012, 38, S657-S660. [CrossRef]

54. Yadav, A.A.; Lokhande, A.C.; Kim, J.H.; Lokhande, C.D. Highly sensitive $\mathrm{CO}_{2}$ sensor based on microrods-like $\mathrm{La}_{2} \mathrm{O}_{3}$ thin film electrode. RSC Adv. 2016, 6, 106074-106080. [CrossRef]

55. Marsal, A.; Dezanneau, G.; Cornet, A.; Morante, J.R. A new $\mathrm{CO}_{2}$ gas sensing material. Sens. Actuators B Chem. 2003, 95, 266-270. [CrossRef]

56. Djerdj, I.; Haensch, A.; Koziej, D.; Pokhrel, S.; Barsan, N.; Weimar, U.; Niederberger, M. Neodymium dioxide carbonate as a sensing layer for chemoresistive $\mathrm{CO}_{2}$ sensing. Chem. Mater. 2009, 21, 5375-5381. [CrossRef]

57. Chen, G.; Han, B.; Deng, S.; Wang, Y.; Wang, Y. Lanthanum dioxide carbonate $\mathrm{La}_{2} \mathrm{O}_{2} \mathrm{CO}_{3}$ nanorods as a sensing material for chemoresistive $\mathrm{CO}_{2}$ gas sensor. Electrochim. Acta 2014, 127, 355-361. [CrossRef]

58. Wang, X.; Qin, H.; Sun, L.; Hu, J. CO $\mathrm{CO}_{2}$ sensing properties and mechanism of nanocrystalline $\mathrm{LaFeO}_{3}$ sensor. Sens. Actuators $B$ Chem. 2013, 188, 965-971. [CrossRef]

59. Wang, X.; Chen, Y.; Qin, H.; Li, L.; Shi, C.; Liu, L.; Hu, J. $\mathrm{CO}_{2}$ sensing of $\mathrm{La}_{0.875} \mathrm{Ca}_{0.125} \mathrm{FeO}_{3}$ in wet vapor: A comparison of experimental results and first-principles calculations. Phys. Chem. Chem. Phys. 2015, 17, 13733-13742. [CrossRef] [PubMed]

60. Diagne, E.H.A.; Lumbreras, M. Elaboration and characterization of tin oxide-lanthanum oxide mixed layers prepared by the electrostatic spray pyrolysis technique. Sens. Actuators B Chem. 2001, 78, 98-105. [CrossRef]

61. Rudraswamy, S.B.; Bhat, N. Optimization of RF sputtered Ag-doped $\mathrm{BaTiO}_{3}-\mathrm{CuO}$ mixed oxide thin film as carbon dioxide sensor for environmental pollution monitoring application. IEEE Sens. J. 2016, 16, 5145-5151. [CrossRef]

62. Zhang, W.; Xie, C.; Zhang, G.; Zhang, J.; Zhang, S.; Zeng, D. Porous $\mathrm{LaFeO}_{3} / \mathrm{SnO}_{2}$ nanocomposite film for $\mathrm{CO}_{2}$ detection with high sensitivity. Mater. Chem. Phys. 2017, 186, 228-236. [CrossRef]

63. Tanvir, N.B.; Yurchenko, O.; Laubender, E.; Pohle, R.; Sicard, O.V.; Urban, G. Zinc peroxide combustion promoter in preparation of $\mathrm{CuO}$ layers for conductometric $\mathrm{CO}_{2}$ sensing. Sens. Actuators B Chem. 2018, 257, 1027-1034. [CrossRef]

64. Marsal, A.; Cornet, A.; Morante, J.R. Study of the $\mathrm{CO}$ and humidity interference in La doped tin oxide $\mathrm{CO}_{2}$ gas sensor. Sens. Actuators B Chem. 2003, 94, 324-329. [CrossRef]

65. Trung, D.D.; Toan, L.D.; Hong, H.S.; Lam, T.D.; Trung, T.; Van Hieu, N. Selective detection of carbon dioxide using LaOClfunctionalized $\mathrm{SnO}_{2}$ nanowires for air-quality monitoring. Talanta 2012, 88, 152-159. [CrossRef]

66. Van Hieu, N.; Khoang, N.D.; Trung, D.D.; Toan, L.D.; Van Duy, N.; Hoa, N.D. Comparative study on $\mathrm{CO}_{2}$ and CO sensing performance of LaOCl-coated ZnO nanowires. J. Hazard. Mater. 2013, 244, 209-216. [CrossRef]

67. Xiong, Y.; Zhang, G.; Zhang, S.; Zeng, D.; Xie, C. Tin oxide thick film by doping rare earth for detecting traces of $\mathrm{CO}_{2}$ : Operating in oxygenfree atmosphere. Mater. Res. Bull. 2014, 52, 56-64. [CrossRef] 
68. Yadav, A.A.; Lokhande, A.C.; Kim, J.H.; Lokhande, C.D. Improvement in $\mathrm{CO}_{2}$ sensing characteristics using Pd nanoparticles decorated $\mathrm{La}_{2} \mathrm{O}_{3}$ thin films. J. Ind. Eng. Chem. 2017, 49, 76-81. [CrossRef]

69. Suzuki, T.; Sackmann, A.; Lauxmann, F.; Berthold, C.; Weimar, U.; Barsan, N. $\mathrm{CO}_{2}$ sensing with gas sensors based on rare-earth compounds: Material exploration. Sens. Actuators B Chem. 2020, 317, 128128. [CrossRef]

70. Krivetskiy, V.; Zamanskiy, K.; Beltyukov, A.; Asachenko, A.; Topchiy, M.; Nechaev, M.; Garshev, A.; Krotova, A.; Filatova, D.; Maslakov, K.; et al. Effect of aupd bimetal sensitization on gas sensing performance of nanocrystalline sno $_{2}$ obtained by single step flame spray pyrolysis. Nanomaterials 2019, 9, 728. [CrossRef] [PubMed]

71. Levan, T.; Che, M.; Tatibouet, J.M.; Kermarec, M. Infrared study of the formation and stability of $\mathrm{La}_{2} \mathrm{O}_{2} \mathrm{CO}_{3}$ during the oxidative coupling of methane on $\mathrm{La}_{2} \mathrm{O}_{3}$. J. Catal. 1993, 142, 18-26. [CrossRef]

72. Jeevanandam, P.; Koltypin, Y.; Palchik, O.; Gedanken, A. Synthesis of morphologically controlled lanthanum carbonate particles using ultrasound irradiation. J. Mater. Chem. 2001, 11, 869-873. [CrossRef]

73. Yamazoe, N.; Shimanoe, K. Theory of power laws for semiconductor gas sensors. Sens. Actuators B Chem. 2008, 128, 566-573. [CrossRef]

74. Yang, L.; Marikutsa, A.; Rumyantseva, M.; Konstantinova, E.; Khmelevsky, N.; Gaskov, A. Quasi similar routes of $\mathrm{NO}_{2}$ and $\mathrm{NO}$ sensing by nanocrystalline $\mathrm{WO}_{3}$ : Evidence by in situ drift spectroscopy. Sensors 2019, 19, 3405. [CrossRef] [PubMed] 